\title{
The species of the bee genus Centris of the "hyptidis group" revisited with the description of Centris (Anisoctenodes) new subgenus (Hymenoptera: Apidae: Centridini)
}

\author{
Felipe VIVALLO \\ HYMN Laboratório de Hymenoptera, Departamento de Entomologia, Museu Nacional, \\ Universidade Federal do Rio de Janeiro, Quinta da Boa Vista, \\ São Cristóvão 20940-040 Rio de Janeiro, RJ, Brazil. \\ Email: fvivallo@yahoo.com \\ urn:Isid:zoobank.org:author:AC109712-1474-4B5D-897B-1EE51459E792
}

\begin{abstract}
In this paper, the species of Centris of the "hyptidis group" are revisited, proposing to recognize them as members of Anisoctenodes subgen. nov., a new subgenus supported by morphological and molecular data. The species included in this new taxon are C. hyptidis Ducke, 1908 (type-species), C. hyptidoides Roig-Alsina, 2000, C. thelyopsis Vivallo \& Melo, 2009 and C. anisitsi (Schrottky, 1908), transferring this latter from Centris (Xanthemisia) Moure, 1945. An updated key, information on the type depository, a distribution map, photographs of both sexes as well as of the diagnostic characters of the new subgenus are also provided.
\end{abstract}

Keywords. Anthophila, Neotropical Region, New World, oil-collecting bees, solitary bees, taxonomy.

Vivallo F. 2020. The species of the bee genus Centris of the "hyptidis group" revisited with the description of Centris (Anisoctenodes) new subgenus (Hymenoptera: Apidae: Centridini). European Journal of Taxonomy 709: 1-17. https://doi.org/10.5852/ejt.2020.709

\section{Introduction}

Centris Fabricius, 1804 is the most diverse lineage of oil-collecting bees in the Western Hemisphere. This genus contains more than 300 described species of which approximately 230 are considered valid (Moure et al. 2007). Throughout the taxonomic history of Centris, various subgenera have been proposed with the objective of grouping the numerous species described in more discrete units that reflect their natural history. Some of those groups, such as C. (Centris), C. (Heterocentris) Cockerell, 1899, C. (Hemisiella) Moure, 1945 and $C$. (Xanthemisia) Moure, 1945 are easily identifiable from morphological characters, while others are more difficult to recognize. In the latter category are those morphologically more heterogeneous subgenera, most of which have their monophyly never been demonstrated.

A small group of South American species phylogenetically related to each other has had a very unsettled taxonomic history. For different reasons, they have been included in several subgenera, although always with some suspicion, due to their particular morphology. Those species, traditionally named as the "hyptidis group", are formed by C. hyptidis Ducke, 1908 (Figs 2B, 3B, 4A-D), C. hyptidoides 
Roig-Alsina, 2000 (Figs 2C, 3C, 5A-D) and C. thelyopsis Vivallo \& Melo, 2009 (Figs 2D, 3D, 6A-D) (Vivallo \& Melo 2009). The "hyptidis group" is a very uniform and clearly monophyletic group, which is supported by both morphological (Vivallo 2004) and molecular data (Martins \& Melo 2016). However, the phylogenetic relationships between it and the other internal lineages of Centris have been subject of some controversy, depending on the type of characters considered.

Morphologically, the species of the "hyptidis group" share some unique morphological characteristics within the genus, highlighting among them the quadrangular shape of the trochanter of fore (Fig. 2A-D) and middle legs in both sexes, and the particular morphology of the fore oil-collecting apparatus (elaiospathe) of the females (Fig. 3A-D), being both diagnostic characteristics for the group (Vivallo 2004; Vivallo \& Melo 2009).

Centris hyptidis has been included arbitrary in Centris s. str. (Aguiar et al. 1995; Aguiar \& Martins 1997), C. (Paracentris) Cameron, 1903 (Vogel \& Machado 1991; Martins 1994; Silveira et al. 2002; Dantas et al. 2004; Moure et al. 2007; Lopes et al. 2010; Feitoza et al. 2014; Silva 2014; Oliveira 2016; Moura et al. 2018), C. (Ptilocentris) Snelling, 1984 (Ayala 1998; Zanella 1999, 2000; Vivallo et al. 2002; Aguiar et al. 2003; Michelette 2005; Pigozzo \& Viana 2010), C. (Ptilotopus) Klug, 1810 (Cockerell 1912) and C. (Wagenknechtia) Moure, 1950 (Giannini et al. 2013). On the other hand, C. hyptidoides was described in C. (Wagenknechtia) (Roig-Alsina 2000), but it was posteriorly transferred to C. (Paracentris) (Moure et al. 2007; Lima \& Silvestre 2017), as well as C. thelyopsis (Moure et al. 2007). In all the cases, the inclusion of any of these species in those subgenera has always transformed them in non-monophyletic groups. The clade formed by $C$. hyptidis and $C$. hyptidoides could be the sister lineage of $C$. (Wagenknechtia) based on morphology (Roig-Alsina 2000; Vivallo 2004). Nevertheless, this supposed relationship is not supported by molecular data. Using nuclear markers $28 \mathrm{~S}, \mathrm{EF}-1 \alpha$, LW $\mathrm{Rh}$ and RNA, the clade formed by the species of the "hyptidis group" appears as a sister group of the clade formed by the subgenera (Trachina Klug (Heterocentris + Hemisiella)) (Martins \& Melo 2016).

During the development of a taxonomic revision of some centridine bees, the holotype of $C$. anisitsi (Schrottky, 1908) (Fig. 1C-D) housed at the Museum für Naturkunde Berlin, Germany (ZMB), was examined. This species is only known from its type specimen collected in Asunción, Paraguay and nothing is known about its bionomy or distribution range. In the subgeneric arrangement of the centridine bees, Moure et al. (2007) included it in C. (Xanthemisia) following the information cited by Schrottky (1908) in the original description about its proximity with C. bicolor Lepeletier, 1841 and C. lutea Friese, 1899.

The detailed study of the type specimen, along with the examination of the undescribed female (Fig. 1A-B) also housed at ZMB, revealed that $C$. anisitsi is not related to $C$. (Xanthemisia) but with the species of the "hyptidis group", sharing the same morphology of fore (Fig. 2A) and middle trochanters as well as the modified fore elaiospathes (Fig. 3A). Thus C. anisitsi becomes the fourth species of this particular lineage of bees. The removal of this species from $C$. (Xanthemisia) transforms this subgenus in a monophyletic group.

Taking into account the unique synapomorphic morphological characters exhibited by the species of the "hyptidis group" (Vivallo 2004) and despite the difficulty of relating the clade formed by them with other internal lineages of Centris, I propose to formally include them in their own subgenus. As mentioned previously, the clade formed by these species has always been recovered in phylogenetic analyzes using both morphological (see Vivallo 2004: fig. 2.2) and molecular (see Martins \& Melo 2016: figs 1-2) data, which supports and justifies its description. 


\section{Material and methods}

The specimens studied are four couples and the primary type of Centris hyptidis (Coleção Entomológica, MNRJ and MPEG), three females, two males and the primary type of C. hyptidoides (MLP and LPBC), the type series of $C$. thelyopsis formed by three females and two males (DZUP), along with the holotype male and the single female known of $C$. anisitsi, both housed at ZMB.

All labels are considered rectangular and yellowish white (by effect of time), and the data is handwritten or printed in black, unless otherwise indicated. The specific features of the labels, such as the coloration or type of writing, are presented in squared brackets ([]). The backward slash (\) indicates different labels on the pin of the same specimen. Specimens marked with a cross ( $\dagger$ ) were lost in the fire of the Museu Nacional Rio de Janeiro on September $2^{\text {nd }}, 2018$. Specimens from others than the MNRJ marked with a cross were in loan at the museum and also lost in the fire.

In the redescription of the holotype of Centris anisitsi (Fig. 1C-D) and the description of its female (Fig. 1A-B), the morphological terminology follows Michener (2007). The morphology of the oilcollecting apparatus (elaiospathes) is according to Snelling (1984) and Neff \& Simpson (1981). Maxillary palpomeres were numbered from the base to the apex. The position of the vertex in relation to the compound eyes was considered in frontal view. Antennal flagellomeres are indicated as F1, F2, etc., and the metasomal terga as $\mathrm{T} 1, \mathrm{~T} 2$, etc.

Photographs were taken using a Leica DFC 450 camera attached to a Leica M205C stereo microscope and using Extended-focus software Leica Application Suite ver. 4.8.0. All images were prepared using the CombineZP ver. 7.0.0.1 software, and then enhanced with Adobe Photoshop ${ }^{\circledR}$ ver. 7.0 without distorting the morphological characters of the specimens. The distribution maps were created based on the records provided by Vivallo \& Melo (2009) and Martins et al. (2013) using QGIS ver. 3.10.1.

\section{Institutional abbreviations}

AMNH $=$ American Museum of Natural History, New York, USA
DZUP $=$ Departamento de Zoologia, Universidade Federal do Paraná, Brazil
LPBC $=$ Laurence Packer Bee Collection, York University, Canada
MNRJ $=$ Museu Nacional Rio de Janeiro, Brazil
MLP $=$ Museo de La Plata, La Plata, Argentina
MPEG $=$ Museu Paraense Emílio Goeldi, Belem, Brazil
NHMUK $=$ Natural History Museum, London, UK
NMBE $=$ Naturhistorisches Museum der Burgergemeinde Bern, Switzerland
ZMB $=$ Museum für Naturkunde Berlin, Germany




\title{
Results
}

Systematics

\author{
Class Insecta Linnaeus, 1758 \\ Order Hymenoptera Linnaeus, 1758 \\ Family Apidae Latreille, 1802 \\ Genus Centris Fabricius, 1804 \\ Anisoctenodes subgen. nov. \\ urn:Isid:zoobank.org:act:9CAFCE9C-F599-465F-91EC-7CD447E19D44
}

\section{Type species}

Centris hyptidis Ducke, 1908.

The species of this new subgenus can be recognized by the shape of the trochanter of fore and middle legs with a basal laminar projection (Fig. 2A-D), and by the fore elaiospathes of the females (Fig. 3A-D) with extremely small posterior giant setae. This rudimentary secondary comb apparently is not used for oil collection, judging by their vestigial condition.

\section{Etymology}

From Greek 'anisos' ('unequal') and 'ctenodes' ('comb-like') based on the particular shape of the fore elaiospathe of the females. The morphology of the oil-collecting apparatuses of the species of this group is unique in Centris which contrasts with the pattern found in the rest of the species of the genus. The shape considered ancestral includes an anterior primary comb formed by a single row of enlarged, flattened and apically curved overlapping setae, and a secondary comb formed by four giant spatulate setae located in opposition to the primary comb (Neff \& Simpson 1981).

\section{Species included}

Centris anisitsi, C. hyptidis, C. hyptidoides and C. thelyopsis.

\section{Remarks}

Most species of Anisoctenodes subgen. nov. exhibit interesting associations with oil-offering flowers, mainly with Angelonia (Plantaginaceae). The species of this genus have trichomatic elaiophores, which require specialized structures for their exploitation (Vogel 1974; Neff \& Simpson 1981). The females have long and branched hairs of spatulate apex (Vogel \& Machado 1991: fig. 9C, G and Martins et al. 2013: fig. 9C-E). These bristles are used for oil collection not through scraping by the elaiophores as in other species of Centris, but by absorption, using capillarity forces (Vogel \& Machado 1991). A detailed description of the oil-collecting apparatus and the collecting behavior of $C$. hyptidis can be found in Machado et al. (2002) and in Martins et al. (2013) for C. hyptidoides.

\section{Distribution}

The species of Anisoctenodes subgen. nov. occur in the South American diagonal of open dry areas formed by the Caatinga, Cerrado, Chacoan and Pampean Provinces. These provinces belong to the Chacoan subregion of the Neotropics (Morrone 2014). Centris hyptidis is distributed mainly in the Caatinga, with peripheral records in the north of the Paraná Forest Province and in the Cerrado. In this latter province also occurs $C$. thelyopsis in the dry forests of the upper Tocantins River (Vivallo \& Melo 2009). Centris anisitsi and C. hyptidoides are distributed in the Chacoan Province, with the latter species also being registered - for the moment by a single record - in the Paraná Forest Province (Fig. 7). 
The description of the morphology of Centris hyptidis, C. hyptidoides and C. thelyopsis, along with their distribution ranges and floral hosts, can be found in Vivallo \& Melo (2009). The redescription of C. anisitsi and the description of the female are provided below.

Centris (Anisoctenodes) anisitsi (Schrottky, 1908)

Figs 1A-D, 2A, 3A, 7

Hemisia anisitsi Schrottky, 1908: 141.

\section{Type data}

This species was described by the German entomologist Curt Schrottky (1874-1937) based on a single male specimen collected by János Dániel Anisits (1856-1911) in Asunción, Paraguay. Anisits was a Hungarian pharmacist, biologist, botanist and researcher who migrated to Paraguay after he graduated as a pharmacist in Budapest. In Paraguay he was head of the Department of Zoology and Botany at the National University. Working actively, he conducted two decades of exploration, collecting biological material and discovering several new species of plants, mainly palm and cactus (Magyarország és LatinAmerika 2019). The labels of the holotype and the additional material are quoted verbatim.
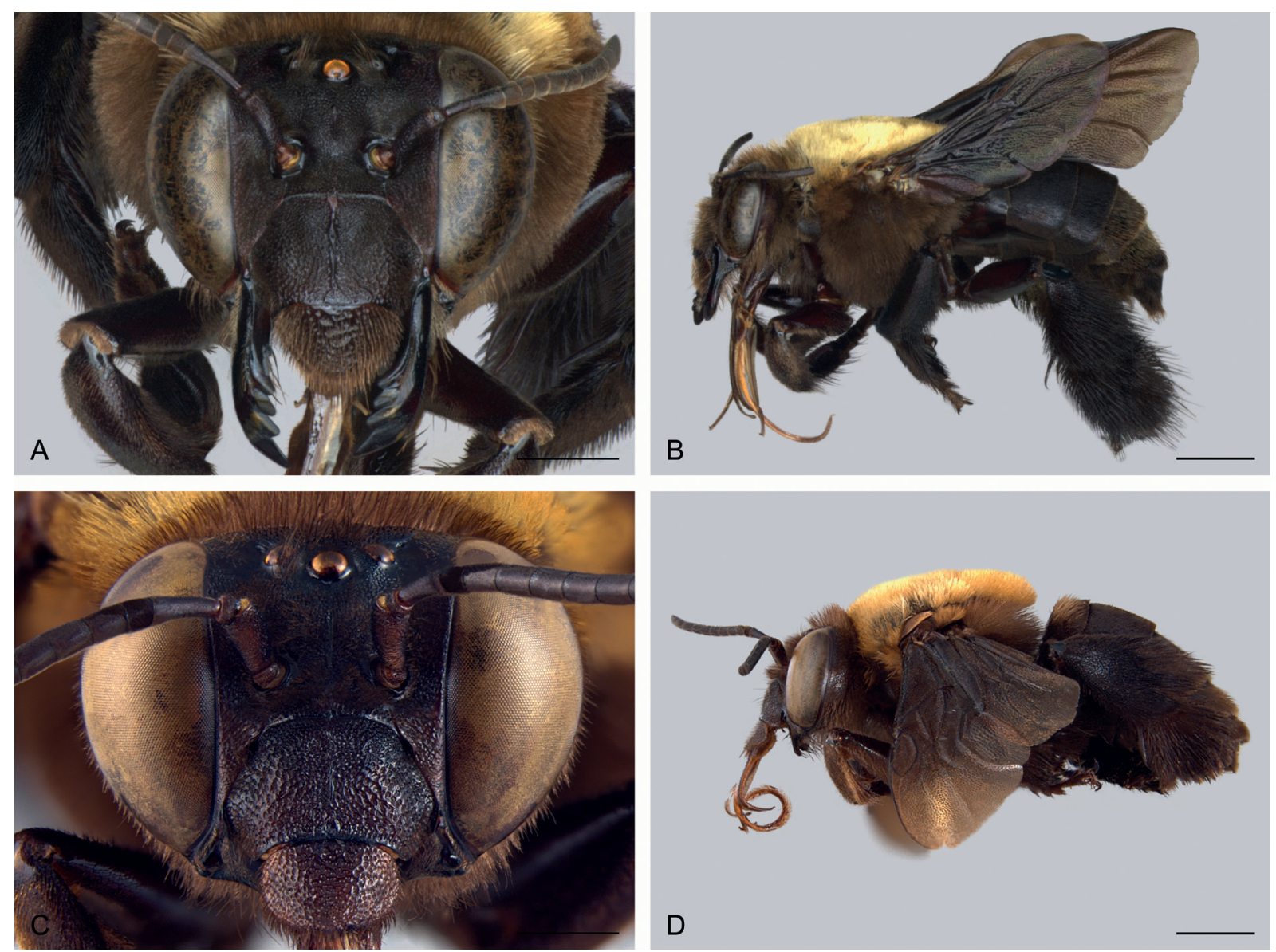

Fig. 1. Centris anisitsi (Schrottky, 1908). A-B. ㅇ, Paraguay, San Bernardino (ZMB †). C-D. ठ̃, Paraguay, Asunción, holotype (ZMB). A, C. Frontal view. B, D. Habitus, lateral view. Scale bars: $1 \mathrm{~mm}$. 


\section{Material examined}

\section{Holotype}

PARAGUAY • đ; "Asuncion, Paraguay J. D. Anisits [printed] XII 04 [handwritten] [red label] Type [handwritten] $\backslash$ Hemisia anisitsi Schrottky $\widehat{\partial}$ [handwritten]”; ZMB.

\section{Additional material}

PARAGUAY • 1 + ; “[green label] Paraguay (San Bernardino) K. Fiebrig S.V. [printed] $\backslash$ Centris anisitsi Schrott. + [handwritten] Strand det. [printed] $\backslash$ Centris burgdorfi v paraguayensis $\mathrm{Fr}$. + [handwritten] 1907 Friese det. [printed]. [Blüh [?]"; ZMB†.

\section{Redescription of the male}

COLORATION. Integument dark brown, slightly lighter to reddish brown on labrum. Tegula yellowish, darker towards anterior margin. Wings light brown (Fig. 1C-D).

INTEGUMENT AND SCULPTURED SURFACE. Clypeus finely areolate towards upper margin, with very coarse and dense punctation, giving it a rough appearance (Fig. 1C). Labrum with similar punctation, with denser and finer punctures towards upper margin (Fig. 1C). T2 and T3 with fine, very dense and uniform
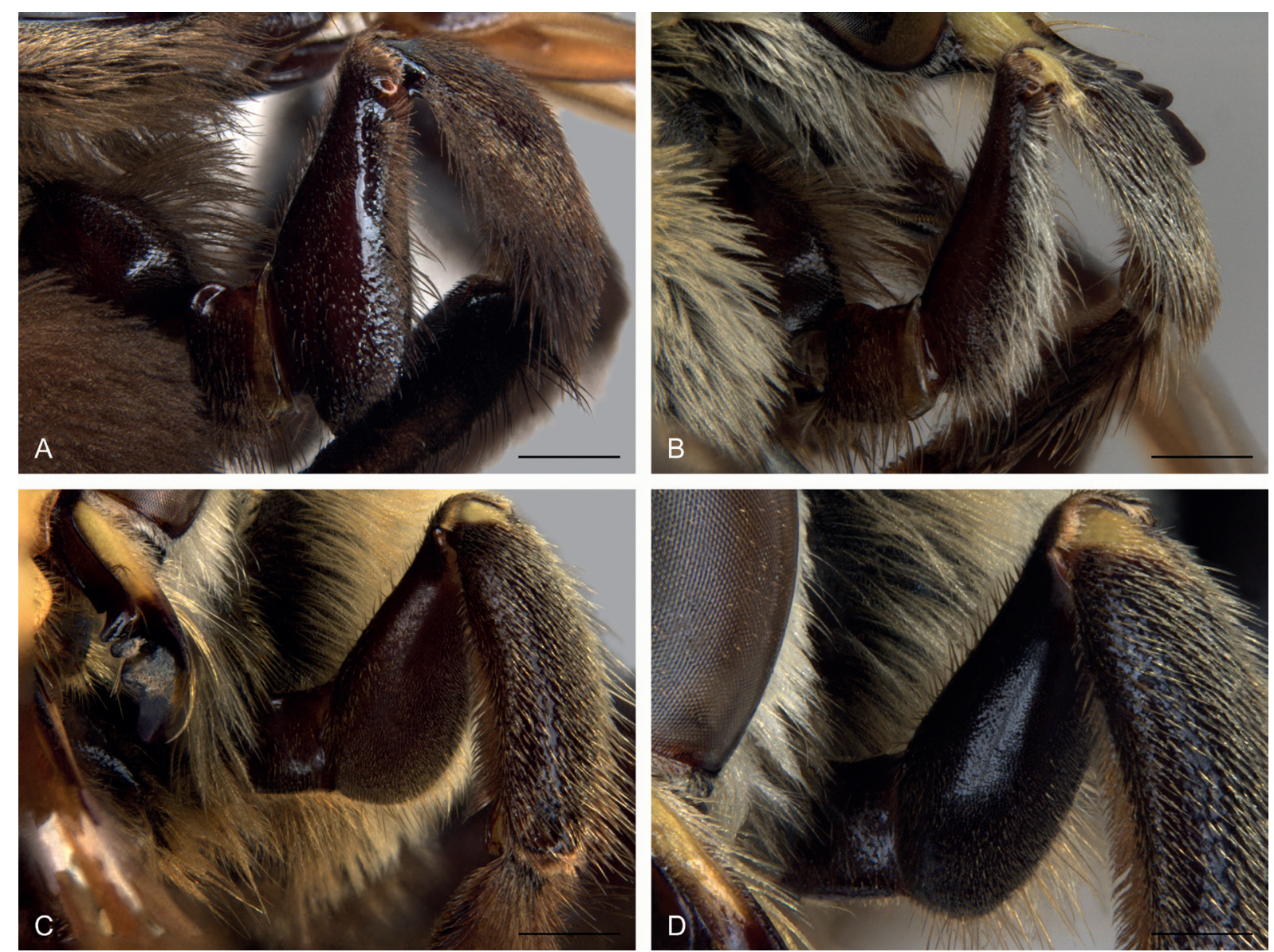

Fig. 2. Trochanter of female fore leg (ZMB †). A. Centris anisitsi (Schrottky, 1908), Paraguay, San Bernardino (LPBC †). B. C. hyptidis Ducke, 1908, Brazil, Vitória da Conquista (MNRJ †). C. C. hyptidoides Roig-Alsina, 2000, Paraguay, San Pedro Cororo (MNRJ †). D. C. thelyopsis Vivallo $\&$ Melo, 2009, Brazil, Teresina de Goiás (DZUP $\dagger$ ). Scale bars: $0.2 \mathrm{~mm}$. 
punctation. T4 and T5 with coarser and disperse puncture. T3-T6 with smooth and translucent distal margins, more evident towards apex of metasoma.

Pubescence. Brown on head, lateral surface of mesepisternum, tegula, legs and metasoma (Fig. 1C-D). Yellow on mesoscutum, mesoscutellum, pronotal lobe (Fig. 1D) and dorsal surface of T1. T3-T6 with brown hairs on distal margins, denser and longer towards apex of metasoma.

STRUCTURES. Flabellum elliptical. Maxillary palpus with four palpomeres $\left(2^{\text {nd }}>3^{\text {rd }}>1^{\text {st }}>4^{\text {th }}\right)$. Mandible with three teeth of acute apex. Trimmal angle poorly developed, obtuse. Lateral area of clypeus parallel to surface of disc, with median longitudinal carina almost reaching upper margin (Fig. 1C). Clypeal disc with lower half concave and upper half convex (lateral view), with two protuberances defining concave transverse area between them. Epistomal suture as curved as lower margin of clypeus (Fig. 1C). Labrum relatively elliptical (Fig. 1C). Inner orbits of compound eyes slightly divergent downwards (Fig. 1C). Ocellocular distance approximately $2.5 \times$ diameter of lateral ocellus (Fig. 1C). Vertex above upper interorbital tangent (Fig. 1C). F1 slightly shorter than scape (Fig. 1C). T7 without pygidial plate, only with triangular glabrous area. Claws with internal tooth.
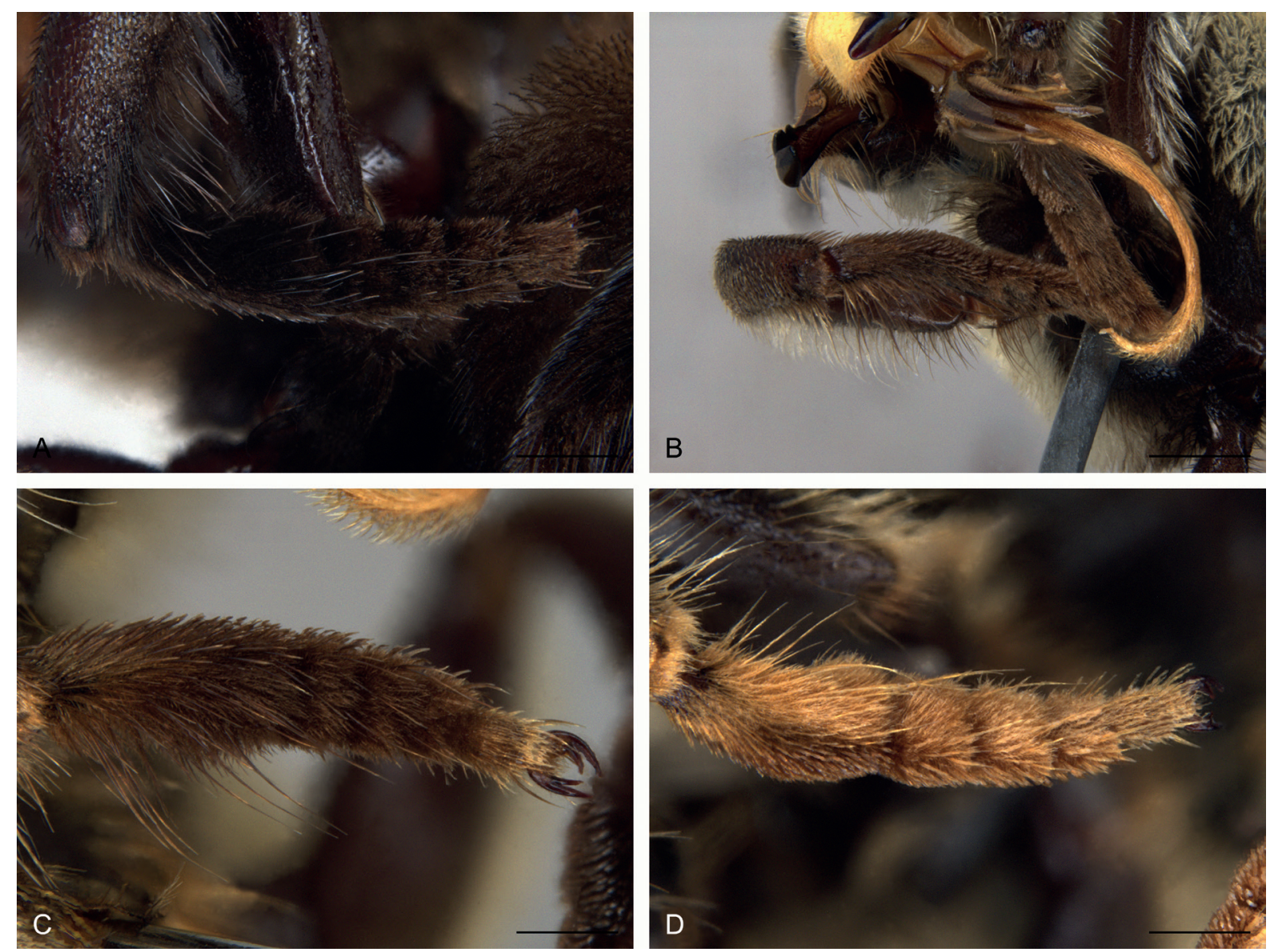

Fig. 3. Elaiospathe of female fore leg. A. Centris anisitsi (Schrottky, 1908), Paraguay, San Bernardino $(\mathrm{ZMB} \dagger)$. B. C. hyptidis Ducke, 1908, Brazil, Vitória da Conquista (MNRJ †). C.C. hyptidoides RoigAlsina, 2000, Paraguay, San Pedro Cororo (LPBC †). D. C. thelyopsis Vivallo \& Melo, 2009, Brazil, Teresina de Goiás (DZUP †). Scale bars: $0.2 \mathrm{~mm}$. 


\section{Description of the female}

COLORATION. Integument dark brown, slightly darker on metasoma. Tegula brownish with lateroposterior margin yellow. Wings brown (Fig. 1A-B).

INTEGUMENT AND SCULPTURED SURFACE. Clypeus with very coarse and dense punctation (giving it a rough appearance), slightly scattered towards lower margin (Fig. 1A); central surface with median, coarse and conspicuous carina between upper and lower margins. Labrum with coarse punctation, more scattered than on clypeus, with finer and denser puncture towards lower margin (Fig. 1A). T2 and T3 with fine, very dense and relatively uniform punctation. Terga and sterna with smooth translucent distal margins, more evident towards apex of metasoma.

Pubescence. Brown on head (Fig 1A), lateral surface of mesepisternum and fore legs (Fig. 1B). Labrum (Fig. 1A), T4 and T5 with light brown pubescence. Dark brown to black on T1-T3, fimbriae and on middle and hind legs (Fig. 1B). Yellow on mesoscutum, mesoscutellum (Fig. 1B) and dorsal surface of T1.

Structures. Flabellum elliptical. Maxillary palpus with four palpomeres $\left(2^{\text {nd }}>3^{\text {rd }}>1 \mathrm{st}>4^{\text {th }}\right)$. Mandible with four apically acute teeth (Fig. 1A). Trimmal angle relatively straight (Fig. 1A). Clypeal disc convex with lower half slightly concave (lateral view). Median portion of epistomal suture relatively parallel to median part of lower margin of clypeus (Fig. 1A). Labrum semicircular (Fig. 1A). Inner orbits of compound eyes slightly convergent downwards (Fig. 1A). Ocellocular distance approximately $2 \times$ diameter of lateral ocellus (Fig. 1A). Vertex above upper interorbital tangent (Fig. 1A). F1 longer than scape (Fig. 1A). Fore and middle trochanters with laminar projection on upper margin (giving them a square appearance) (Fig. 2A). Basitibial plate with an ill-defined S-like secondary plate (lower margin diffused). Secondary plate of pygidial plate with lateral margins converging distally, but not reaching each other. Claws with internal tooth.

\section{Distribution}

This species has only been recorded in Paraguay (Capital District: Asunción; Cordillera Department: San Bernardino) (Fig. 7).

\section{Remarks}

This is a rare species and unfortunately nothing is known about its bionomy. However, some of the pollen grains found on the scopa indicate that the female visited Bauhinia sp. (Caesalpiniaceae D.C., 1825), Borreria sp. (Rubiaceae Juss.), Melochia sp. (Sterculiaceae Beilschm.), Fabaceae Lindl., Caricaceae Dumort. (or Loranthaceae Juss.) and Bignoniaceae Juss.

Centris (Anisoctenodes) hyptidis Ducke, 1908

Figs 2B, 3B, 4, 7

Centris hyptidis Ducke, 1908: 75-76.

Centris (Ptilotopus) libertatis Cockerell, 1912: 44-45. Junior synonym (Moure et al. 2007).

\section{Type data}

Centris hyptidis was described by the Italian botanist and entomologist Adolf (Adolpho) Ducke (1876-1959) based on an undetermined number of female specimens collected in Baturité, Ceará state, northeastern Brazil. The lectotype female was designated by Nascimento (1979), the labels are quoted verbatim. 
Cockerell described Centris (Ptilotopus) libertatis based on a single female collected at "Independencia", Paraíba state, northeastern Brazil by Harold Heath (1868-1951) and William Mann (1886-1960), both members of the Stanford Expedition (Oliveira 2014). The type specimen is currently housed at AMNH, the label is quoted verbatim.

\section{Material examined}

\section{Lectotype of Centris hyptidis}

BRAZIL • 1 9; Ceará state, Baturité; “Ceará Baturité 29-6-1908 Ducke [handwritten] Brazil Estado do Ceará [printed] [white label] Centris hyptidis Ducke Lectotypus Moure \& Michener 1955 [handwritten in red] [white label with black rim] MPEG-HYM 11078022 [printed]"; MPEG.

\section{Paralectotypes of Centris hyptidis}

BRAZIL • 1 क; Ceará state, Baturité; “Ceará Baturité 29-8-1908 Ducke [handwritten] Brazil. Mus. Goeldi. 1910-90. [printed] \Centris hyptidis Ducke Type + [handwritten \[circular red rimmed label] Type [printed] B.M.TYPE HYM.[printed] 17B.910. [handwritten]"; NHMUK • 1 क; Ceará state, Baturité; "Ceará Baturité 29-6-1908 Ducke [handwritten]\Centris hyptidis Ducke Typ. + [handwritten] [red label] Typus [printed]"; NMBE.
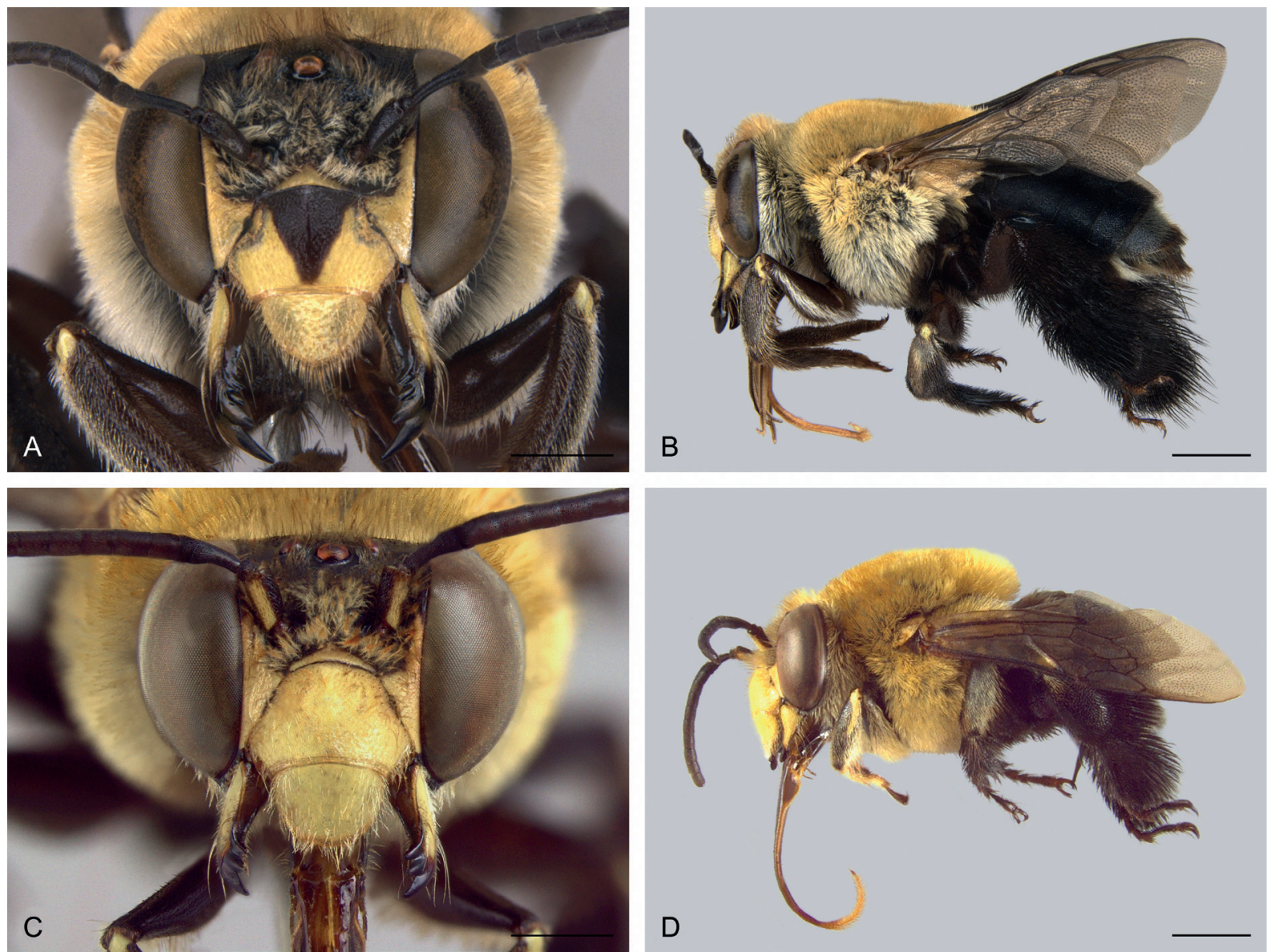

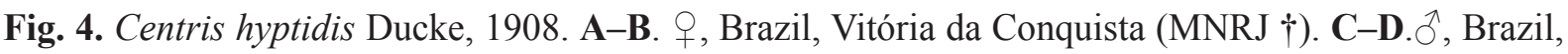
Vitória da Conquista (MNRJ †). A, C. Frontal view. B, D. Habitus, lateral view. Scale bars: $1 \mathrm{~mm}$. 


\section{Holotype of Centris (Ptilotopus) libertatis}

BRAZIL • P; Paraíba state, Independência; "Independencia, Parahyba, Brazil Mann \& Heath. [printed] Centris libertatis Ckll Type. [handwritten] $\backslash$ ac33337 [handwritten] $\backslash$ AMNH_IZC 00323438 QR code [printed]"; AMNH.

\section{Additional material}

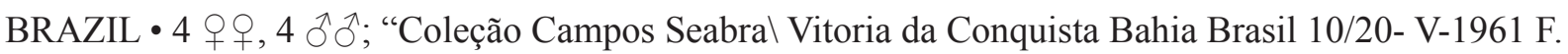
M. Oliveira"; MNRJ †.

\section{Distribution}

This is the most widely distributed species of $C$. (Anisoctenodes) subgen. nov., with records in the Brazilian states of Bahia, Ceará, Goiás, Minas Gerais, Paraíba, Pernambuco, Piauí, Rio Grande do Norte, Sergipe and Tocantins (Vivallo \& Melo 2009; Martins et al. 2013) (Fig. 7).

\section{Centris (Anisoctenodes) hyptidoides Roig-Alsina, 2000} Figs 2C, 3C, 5, 7

Centris (?Wagenknechtia) hyptidoides Roig-Alsina, 2000: 190-191.
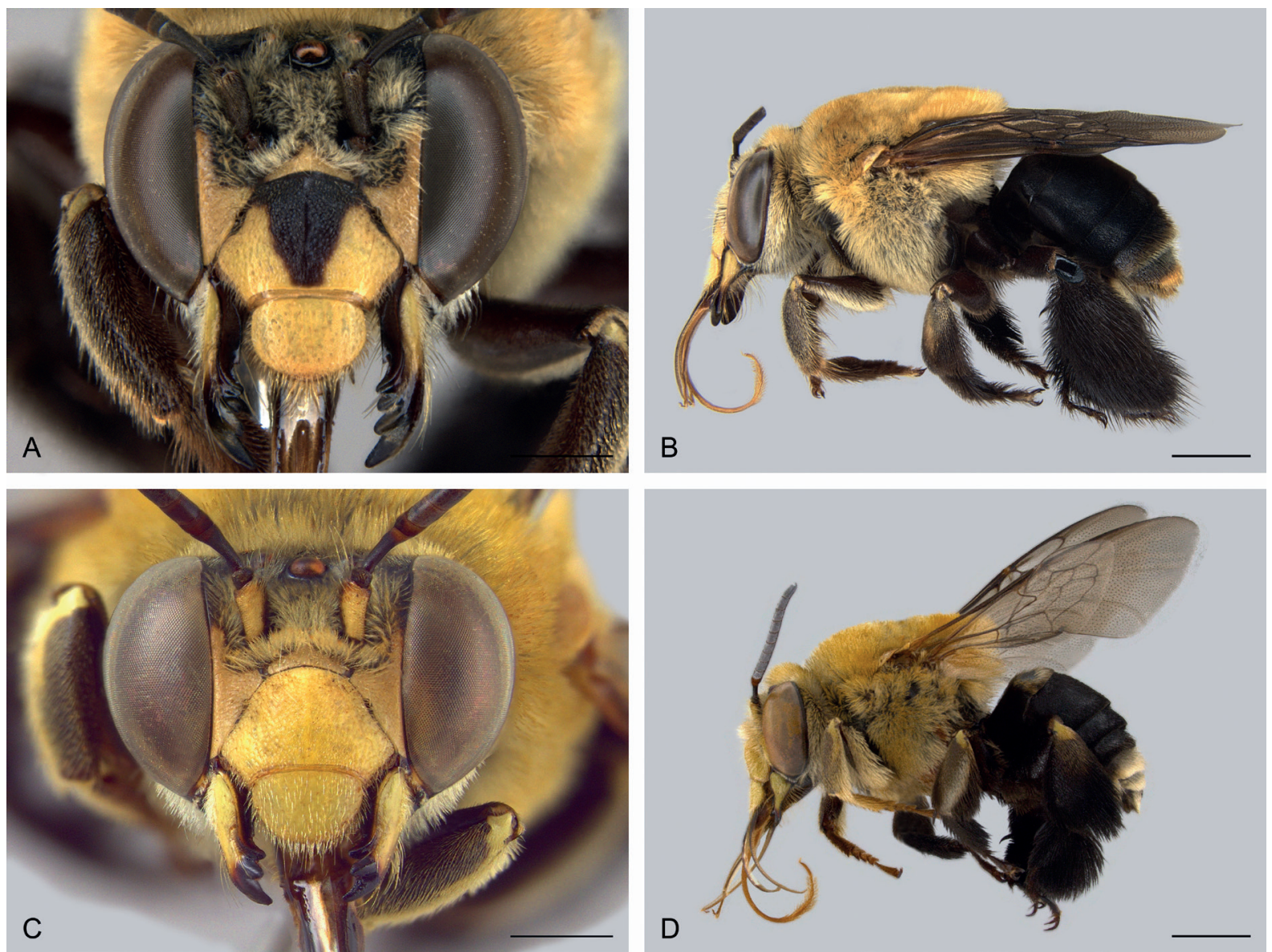

Fig. 5. Centris hyptidoides Roig-Alsina, 2000. A-B. \&, Paraguay, San Pedro Cororo (LPBC $\dagger$ ). C-D. $\circlearrowright$, Paraguay, San Pedro Cororo (LPBC †). A, C. Frontal view. B, D. Habitus, lateral view. Scale bars: $1 \mathrm{~mm}$. 


\section{Type data}

The single female specimen used to describe this species was collected by the Argentinean ornithologist Juan Bautista Daguerre (1890-1975) at Las Lomitas, central region of Formosa Province, northeastern Argentina. The labels of the holotype are quoted verbatim.

\section{Material examined}

\section{Holotype}

ARGENTINIA - + ; Las Lomitas, central region of Formosa Province; "[white label] Las Lomitas Terr. de Formosa 12/1950 J. B. Daguerre [handwritten] [red label with black rim] Centris hyptidoides † sp. n. A. Roig Alsina 2000 [handwritten] HOLOTYPUS [printed]”; MLP.

\section{Additional material}

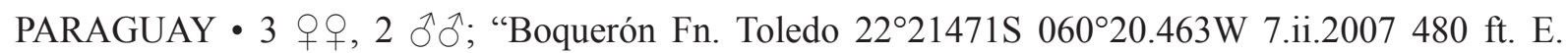
Willis"; LPBC $\dagger$.

\section{Distribution}

This species has been recorded in Argentina (Formosa Province: Las Lomitas) (Roig-Alsina 2000), Brazil (Mato Grosso state: Porto Murtinho) (Vivallo \& Melo 2009; Martins et al. 2013) and Paraguay (Boquerón Department: Toledo; San Pedro Department: Cororo) (Vivallo \& Melo 2009) (Fig. 7).

\section{Centris (Anisoctenodes) thelyopsis Vivallo \& Melo, 2009}

Figs 2D, 3D, 6-7

Centris thelyopsis Vivallo \& Melo, 2009: 40-41.

\section{Material examined}

Holotype

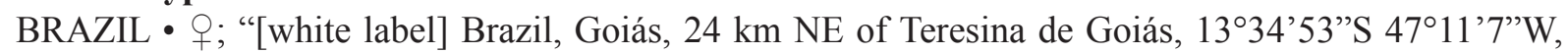
450m, 05.iv.2003, Melo, Aguiar, Marchi and Gonçalves [printed] em Angelonia [handwritten] [red label] HOLOTYPE Centris thelyopsis Vivallo \& Melo, 2009 [printed]"; DZUP.

\section{Paratypes}

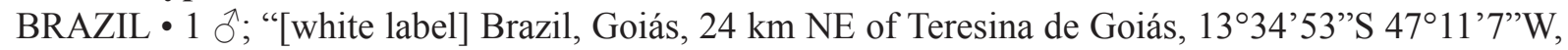
450m, 05.iv.2003, Melo, Aguiar, Marchi and Gonçalves em Angelonia [handwritten] [yellow label] PARATYPE Centris thelyopsis Vivallo \& Melo, 2009 [printed]"; DZUP • 1 ơ; "[white label] Brazil,

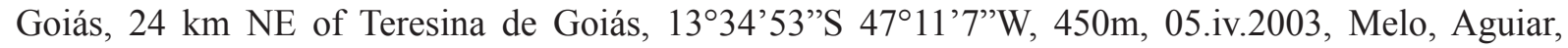
Marchi and Gonçalves em Angelonia [handwritten] [yellow label] PARATYPE Centris thelyopsis Vivallo \& Melo, 2009 [printed]”; DZUP $\uparrow \bullet 1$ \&; “[white label] Brazil, Goiás, 24 km NE of Teresina de Goiás, 1334'53'S 47¹1'7’W, 450m, 05.iv.2003, Melo, Aguiar, Marchi and Gonçalves em Angelonia [handwritten] [yellow label] PARATYPE Centris thelyopsis Vivallo \& Melo, 2009 [printed]";

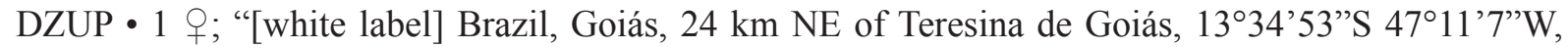
450m, 05.iv.2003, Melo, Aguiar, Marchi and Gonçalves em Angelonia [handwritten] [yellow label] PARATYPE Centris thelyopsis Vivallo \& Melo, 2009 [printed]"; DZUP †.

\section{Distribution}

This species occurs exclusively in Brazil, with distribution records in Teresina de Goiás (Goiás state) (Vivallo \& Melo 2009; Martins et al. 2013) (Fig. 7). 


\section{Key to the species of Centris (Anisoctenodes) subgen. nov.}

Modified from Vivallo \& Melo (2009).

1. Head without yellow areas (Fig. 1A, C). Clypeus with coarse and very dense punctation, with conspicuous median longitudinal carina (Fig. 1A). Lateral surface of mesepisternum with brown pubescence (Fig. 1B, D). Male with fore and middle legs with brown pubescence (Fig. 1D) .....

Centris anisitsi (Schrottky, 1908)

- Head with yellow areas (Figs 4A, C, 5A, C, 6A, C). Clypeus with relatively fine and not extremely dense punctation, without conspicuous median longitudinal carina. Lateral surface of mesepisternum with yellowish pubescence (Figs 4B, D, 5B, D, 6B, D). Male with fore and middle legs with yellowish pubescence, at least in part (Figs $4 \mathrm{C}-\mathrm{D}, 5 \mathrm{C}-\mathrm{D}, 6 \mathrm{C}-\mathrm{D})$

2. Metasoma with bands of orange pilosity (Fig. 6B, D). Hind leg with yellowish pubescence (Fig. 6B, D). Clypeus of male yellow with a large triangular black spot in the middle (Fig. 6C)

Centris thelyopsis Vivallo \& Melo, 2009

- Metasoma with predominantly black pubescence (except T1, with yellow pilosity and the last two terga with white pilosity) (Figs 4B, D, 5B, D). Hind leg with predominantly black pubescence (Figs 4B, D, 5B, D). Male with clypeus entirely yellow (Figs 4C, 5C)
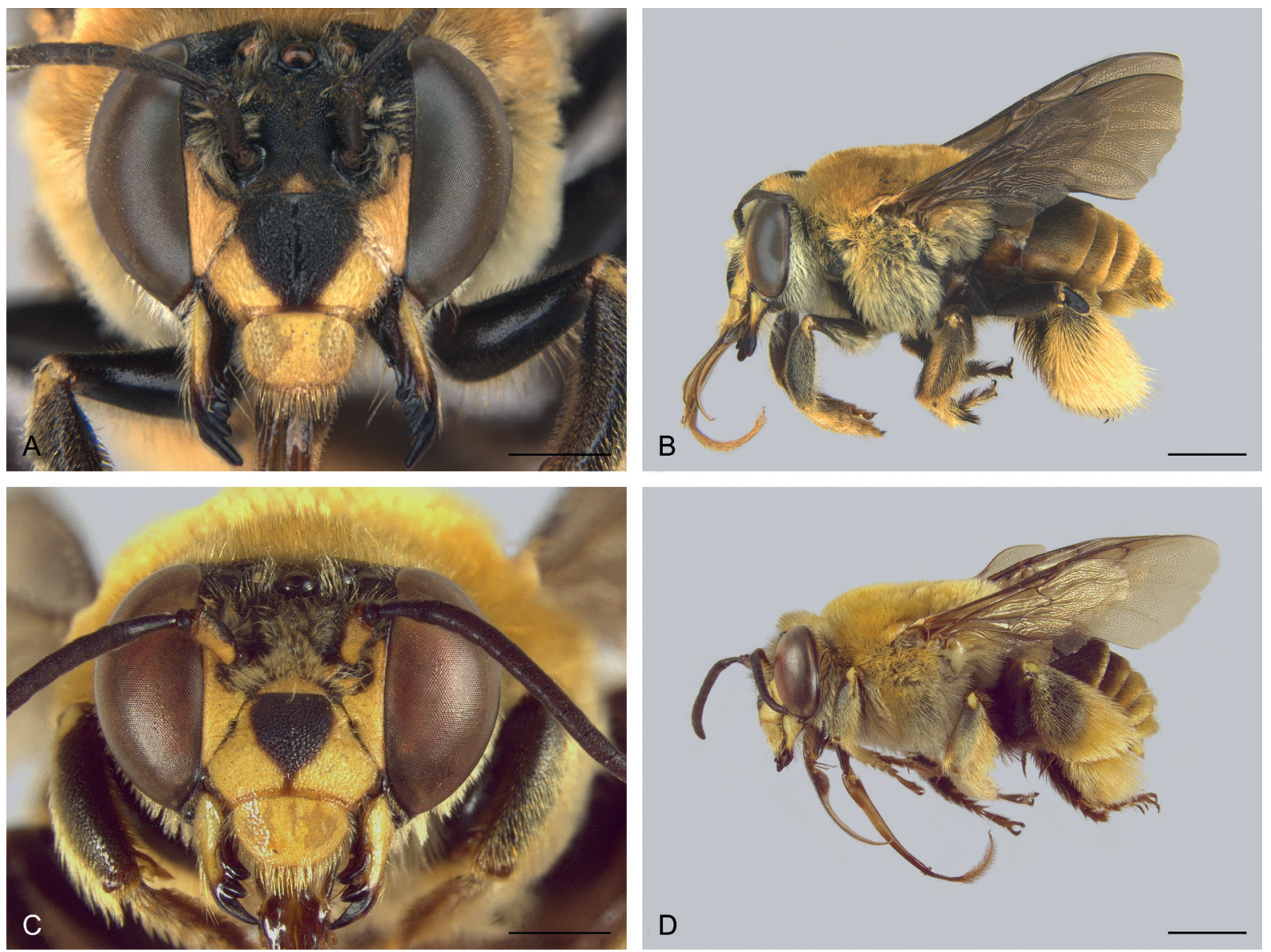

Fig. 6. Centris thelyopsis Vivallo \& Melo, 2009, paratypes. A-B. + , Brazil, Teresina de Goiás (DZUP $\dagger$ ). C-D. $\overbrace{}^{\top}$, Brazil, Teresina de Goiás (DZUP †). A, C. Frontal view. B, D. Habitus, lateral view. Scale bars: $1 \mathrm{~mm}$. 
3 : fore elaiospathe with four secondary posterior giant setae beside the primary anterior comb. T4 with yellowish pilosity at least on distal margin (Fig. 5B). 0 : T1 with uninterrupted band of yellowish pilosity. F1 $3.2 \times$ as long as F2. Apical margin of T4 with a complete narrow band of plumose hairs

Centris hyptidoides Roig-Alsina, 2000

- $O$ : fore elaiospathe without secondary posterior giant setae beside the primary anterior comb. T4 with predominantly black pilosity sometimes with some yellow hairs intermixed (Fig. 4B). O: T1 with band of yellowish pilosity generally interrupted in the middle. F1 $2.9 \times$ as long as F2. Apical margin of T4 with narrow band of plumose hairs restricted to lateral portions of tergum

Centris hyptidis Ducke, 1908

\section{Discussion}

The formal recognition of Centris (Anisoctenodes) as a new subgenus allows a better organization of and clarity on the phylogenetic relationships between certain groups of species within Centris. The removal of the species of the "hyptidis group" sensu Moure et al. (2007) from C. (Paracentris) allows recognizing that it is not related to the species of that subgenus, as well as contributing to our better understanding of the latter taxon. Centris (Paracentris), along with C. (Melanocentris) Friese, 1901, are the two subgenera with the highest specific richness and they include the species most difficult to identify. It is expected that both groups will undergo further modifications with respect to the number of species they have, once the taxonomy and the morphology of their species is studied.

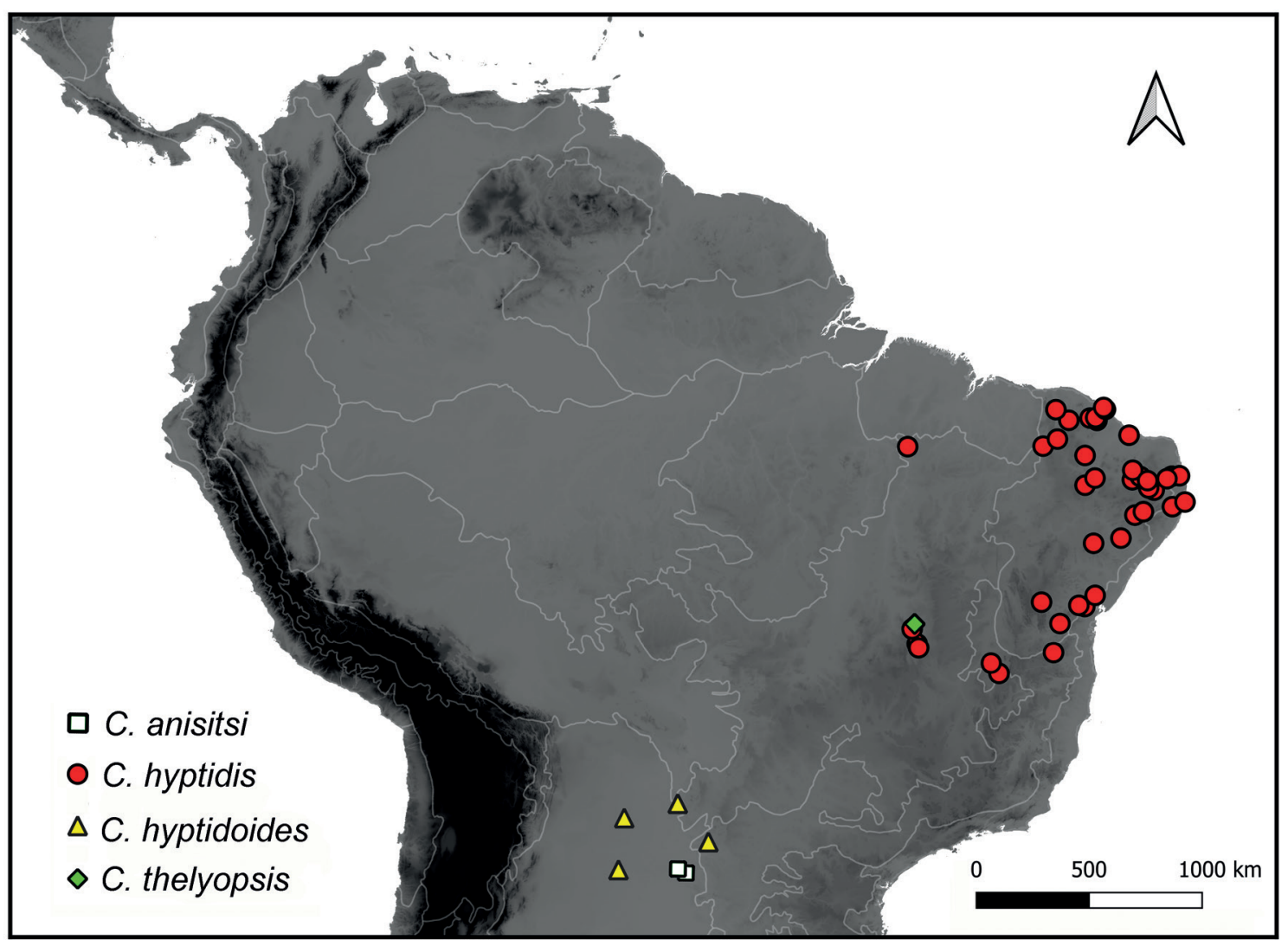

Fig. 7. Distribution map of the species of Centris (Anisoctenodes) subgen. nov. 
The removal of C. anisitsi from C. (Xanthemisia), its recognition as a member of the "hyptidis group" and its subsequent inclusion in $C$. (Anisoctenodes) subgen. nov. allows recognizing the former subgenus as a monophyletic group. Now including only species that share the very particular morphology of the mandible and the pygidial plate of the females that characterizes this group.

The species of $C$. (Anisoctenodes) subgen. nov. occur in the South American diagonal of dry open areas. This distribution pattern is very interesting from the biogeographic point of view, so new research focused on this fact could contribute significantly to the knowledge of the relationships between the biogeographic provinces that compose the Chacoan dominion. According to Martins \& Melo (2016), this group of bees arose approximately 35 million of years ago during the Eocene, being a relatively old lineage within the genus.

Among the species of this new subgenus only $C$. hyptidis and $C$. hyptidoides have been studied relatively in detail, mainly as pollinators. Unfortunately, the knowledge of the bionomy of $C$. anisitsi and in a certain way of $C$. thelyopsis is almost completely unknown.

\section{Acknowledgments}

I thank Jerome Rozen and Corey Smith (AMNH), Gabriel Melo (DZUP), Laurence Packer (LPBC), Mariano Lucia (MLP), Orlando Tobias (MPEG), David Notton (NHMUK), Elsa Obrecht and Christoph Germann (NMBE), Michael Ohl (ZMB), Danny Vélez, Diego Marinho and Claudia Barbieri (MNRJ) as well as the anonymous reviewers for their help. Financial support was provided by the Conselho Nacional de Desenvolvimento Científico e Tecnológico (CNPq, grant 444320/2014-8), Brazil, and the Projeto de Informatização da Coleção Entomológica do Museu Nacional/UFRJ, SIBBR/CNPq (proc. 405588/2015-1). This paper is part of the SIGMA project N21565 MN/UFRJ and the contribution number 47 from the HYMN.

\section{References}

Aguiar A.J.C. \& Martins C.F. 2003. The bee diversity of the Tabuleiro vegetation in the Guaribas Biological Reserve (Mamanguape, Paraíba, Brazil). In: Melo G.A.R. \& Alves-dos-Santos I. (eds) Apoidea Neotropica: Homenagem aos 90 anos de Jesus Santiago Moure: 209-216. UNESC, Criciúma.

Aguiar C.M.L. \& Martins C.F. 1997. Abundância relativa, diversidade e fenologia de abelhas (Hymenoptera, Apoidea) na Caatinga, São João do Cariri, Paraíba, Brasil. Iheringia Série Zoologia 83: $151-163$.

Aguiar C.M.L., Martins C.F. \& Moura A. 1995. Recursos florais utilizados por abelhas (Hymenoptera, Apoidea) em área da Caatinga (São João do Cariri, Paraíba). Revista Nordestina de Biologia 10: 101117.

Aguiar C.M.L., Zanella F.C.V., Martins C.F. \& Carvalho C.A.L. 2003. Plantas visitadas por Centris spp. (Hymenoptera: Apidae) na Caatinga para obtenção de recursos florais. Neotropical Entomology 32: $247-259$.

Ayala R. 1998. Sistemática de los taxa supraespecificos de las abejas de la tribu Centridini (Hymenoptera: Anthophoridae). Ph.D. Thesis. Universidad Autónoma de México, México, D.F.

Dantas J.O., Oliveira D.A. \& Mendonça M.C. 2000. Lista preliminar das abelhas da região de Sergipe (Hymenoptera, Apoidea). Biologia Geral e Experimental 1: 19-21.

Feitoza E.A., Silva T.A., Silva M.P., Santos C.T.G.P. \& Kiill L.H.P. 2014. Interações de plantas e abelhas da Caatinga no Polo Petrolina, PE - Juazeiro, BA. Jornada de Iniciação Científica da Embrapa Semiárido 9: 35-40. 
Giannini T.C., Pinto C.E., Acosta A.L., Taniguchi M., Saraiva A.M. \& Alves-dos-Santos I. 2013. Interactions at large spatial scale: the case of Centris bees and floral oil producing plants in South America. Ecological Modelling 258: 74-78. https://doi.org/10.1016/j.ecolmodel.2013.02.032

Gomes L.F., Badke J.P., Zama U., Dolder H. \& Lino-Neto J. 2012. Morphology of the male reproductive system and spermatozoa in Centris Fabricius, 1804 (Hymenoptera: Apidae, Centridini). Micron 43 (6) 695-704.

Lima F.V.O. \& Silvestre R. 2017. Abelhas (Hymenoptera, Apidae sensu lato) do Estado de Mato Grosso do Sul, Brasil. Iheringia, série Zoologia 107 (suplemento 0).

https://doi.org/10.1590/1678-4766e2017123

Lopes M.T.R., Reis A.S., Souza B.A., Pereira F.M., Oliveira F.F., Neves L.S.M.L., Pereira L.A., Rocha F.S.B. \& Vieira Neto J.M. 2010. Levantamento da fauna e plantas apícolas na Embrapa Meio-Norte, em Teresina, PI. Boletim de Pesquisa e Desenvolvimento. Empresa Brasileira de Pesquisa Agropecuária Embrapa Meio-Norte. Ministério da Agricultura, Pecuária e Abastecimento.

Machado I.C., Vogel S. \& Lopes A.V. 2002. Pollination of Angelonia cornigera Hook (Scrophulariaceae) by long legged, oil-collecting bees in NE Brazil. Plant Biology 4: 352-359.

https://doi.org/10.1055/s-2002-32325

Magyarország és Latin-Amerika. 2019. Magyarország és Latin-Amerika. Közös Múlt És Jelen. Available from https://latam.kormany.hu/anisits-janos-daniel [accessed 12 Oct. 2019].

Martins A.C. \& Melo G.A.R. 2016. The New World oil-collecting bees Centris and Epicharis (Hymenoptera, Apidae): molecular phylogeny and biogeographic history. Zoologica Scripta 45: 22-33. https://doi.org/10.1111/zsc.12133

Martins A.C., Aguiar A.J.C. \& Alves-dos-Santos I. 2013. Interaction between oil-collecting bees and seven species of Plantaginaceae. Flora - Morphology Distribution Functional Ecology of Plants 208 (7): 1-11. https://doi.org/10.1016/j.flora.2013.07.001

Martins C.F. 1994. Comunidade de abelhas (Hym. Apoidea) da Caatinga e do Cerrado com elementos de Campo Rupestre do Estado da Bahia, Brasil. Revista Nordestina de Biologia 9: 225-257.

Michelette E.R.F. 2005. Distribuição local das abelhas. In: Carvalho C.M. \& Vilar J.C. (eds) Parque Nacional Serra de Itabaiana-Levantamento da Biota. Ibama, Biologia Geral e Experimental-UFS, Aracaju.

Michener C.D. 2007. The Bees of the World. $2^{\text {nd }}$ Edition. Johns Hopkins University Press, Baltimore.

Morrone J.J. 2014. Biogeographical regionalisation of the Neotropical Region. Zootaxa 3782 (1): 1-110. https://doi.org/10.11646/zootaxa.3782.1

Moura D.C., Pereira T.M.S., Farias G.C. \& Leite J.E.M. 2018. Abelhas e espécies melitófilas da mata ciliar do riacho Salgadeira, município de Alcantil, Paraíba. Revista Verde de Agroecologia e Desenvolvimento Sustentável 13 (3): 392-398.

Moure J.S., Melo G.A.R. \& Vivallo F. 2007. Centridini Cockerell \& Cockerell. In: Moure, J.S., Urban, D. \& Melo, G.A.R. (orgs) Catalogue of Bees (Hymenoptera, Apoidea) in the Neotropical Region: 83-142. Sociedade Brasileira de Entomologia, Curitiba, Brazil.

Nascimento P.T.R. 1979. Catálogo de tipos entomológicos do Museu Goeldi. Hymenoptera. Boletim do Museu Paraense Emílio Goeldi, Zoologia 98: 1-17.

Neff J.L. \& Simpson B.B. 1981. Oil-collecting structures in the Anthophoridae (Hymenoptera): morphology, function and use in systematics. Journal of the Kansas Entomological Society 54: 95-123. 
Oliveira A.L. 2014. O litoral do Nordeste do Brasil como objeto científico darwinista: as prospecções de John Casper Branner, 1899-1911. História, Ciências, Saúde - Manguinhos 21 (3): 931-949. https://doi.org/10.1590/S0104-59702014000300008

Oliveira F.S. 2016. Ecologia da polinização e análise da composição química do óleo floral de duas espécies de Mouriri (Melastomataceae) e sua importância na atração dos visitantes florais. Ph.D. Thesis. Programa de Pós-Graduação em Biodiversidade e Biotecnologia da Amazônia Legal). Universidade Federal do Maranhão, São Luís, Brazil.

Pigozzo C.M. \& Viana B.F. 2010. Estrutura da rede de interações entre flores e abelhas em ambiente de Caatinga. Oecologia Australis 14 (1): 100-114.

Roig-Alsina A. 2000. Claves para las especies argentinas de Centris (Hymenoptera, Apidae), con descripción de nuevas especies y notas sobre distribución. Revista del Museo Argentino de Ciencias Naturales n.s. 2: 171-193.

Schrottky C. 1908. Die bisher aus Paraguay bekannten Arten der Bienengattungen Epicharis und Hemisia. (Hym.). Zeitschrift für Systematische Hymenopterologie und Dipterologie 8: 138-143.

Silva E.M. 2014. Lista de espécies de Apidae (Hymenoptera) do semiárido com base na literatura especializada. In: Bravo F. \& Calor A. (eds) Artrópodes do Semiárido Biodiversidade e Conservação: 181-202. Feira de Santana: Printmídia.

Silveira F.A., Melo G.A.R. \& Almeida E.A.B. 2002 Abelhas Brasileiras: Sistemática e Identificação. F. A. Silveira, Belo Horizonte.

Snelling R.R. 1984. Studies on the taxonomy and distribution of American Centridine bees (Hymenoptera: Anthophoridae). Contributions in Science 347: 1-69.

Vivallo F. 2004. Sistemática, filogenia y distribución geográfica de las especies del género Centris Fabricius, con énfasis en los subgéneros Wagenknechtia Moure, 1950, Ptilocentris Snelling, 1984 y Aphemisia Ayala, 2002, incluyendo un análisis del grupo Melacentris. M.Sc. Thesis. Pontificia Universidad Católica de Valparaíso, Valparaíso, Chile.

Vivallo F. \& Melo G.A.R. 2009. Taxonomy and geographic distribution of the species of Centris of the hyptidis group (Hymenoptera: Apidae: Centridini), with a description of a new species from Central Brazil. Zootaxa 2075: 33-44. https://doi.org/10.11646/zootaxa.2075.1.2

Vivallo F., Zanella F.C.V. \& Toro H. 2002. Las especies chilenas de Centris (Wagenknechtia) Moure, 1950 (Hymenoptera: Apidae). Acta Entomológica Chilena 26: 59-80.

Vogel S. 1974. Ölblumen und ölsammelnde Bienen. Tropische und Subtropische Pflanzenwelt 7. Steiner, Wiesbaden.

Vogel S. \& Machado I.C. 1991. Pollination of four sympatric species of Angelonia (Scrophulariaceae) by oil-collecting bees in NE, Brazil. Plant Systematics and Evolution 178: 153-178.

https://doi.org/10.1007/BF00937962

Zanella F.C.V. 1999. Aspectos biogeográficos da apifauna da Caatinga, com contribuições à sistemática de Caenonomada Ashmead, 1899 e Paracentris Cameron, 1903 (Hymenoptera, Apoidea, Apidae). Ph.D. Thesis. Universidade de São Paulo, São Paulo, Brazil.

Zanella F.C.V. 2000. The bees of the Caatinga (Hymenoptera, Apoidea, Apiformes): a species list and comparative notes regarding their distribution. Apidologie 31: 579-592.

https://doi.org/10.1051/apido:2000148 
Manuscript received: 12 December 2019

Manuscript accepted: 17 July 2020

Published on: 27 August 2020

Topic editor: Nesrine Akkari

Section editor: Gavin Broad

Desk editor: Eva-Maria Levermann

Printed versions of all papers are also deposited in the libraries of the institutes that are members of the EJT consortium: Muséum national d'histoire naturelle, Paris, France; Meise Botanic Garden, Belgium; Royal Museum for Central Africa, Tervuren, Belgium; Royal Belgian Institute of Natural Sciences, Brussels, Belgium; Natural History Museum of Denmark, Copenhagen, Denmark; Naturalis Biodiversity Center, Leiden, the Netherlands; Museo Nacional de Ciencias Naturales-CSIC, Madrid, Spain; Real Jardín Botánico de Madrid CSIC, Spain; Zoological Research Museum Alexander Koenig, Bonn, Germany; National Museum, Prague, Czech Republic. 